\title{
PERKEMBANGAN NILAI BUDAYA KESENIAN RANTAK KUDO SEBAGAI WARISAN BUDAYA KERINCI
}

\author{
Ediantes \\ Program Studi Televisi dan Film, Institu Seni Indonesia Padangpanjang \\ Jl. Bahder Johan, Guguk Malintang, Padang Panjang Tim., Kota Padang Panjang, Sumatera Barat \\ Email : antes.isipp@gmail.com
}

\begin{abstract}
The development of Rantak Kudo Art is a performing arts phenomenon that occurs in the Kerinci area, in this dance performance is not performed specifically by the dancers, but is danced by the local community who mingle with each other while accompanying music produced from single organ and traditional musical instruments such as flutes and drums. Another unique thing is that this dance is performed all night, meaning that the dance participants are able to dance for more than 6 hours continuously, so that people think that Rantak Kudo dancing is accompanied by magical elements in the performance. At this time the art in the form of mass dances was present at every traditional art activity and event, although it was alleged that the Rantak Kudo art was influenced by the Rantak Kudo dance that developed in the South Coast and also the Rantak Kudo dance from the Rawang area. In particular, this study aims to reveal the forms and cultural values of Rantak Kudo art in the Kerinci area. The research methodology used in this study is postpositivism qualitative research, which is a method that not only analyzes the appearance, but also uses statistical methods and documents as a means to place groups of subjects into a larger population. The results of this study can be grouped into several points, including the cultural form of Rantak Kudo art, the cultural values contained in the Rantak Kudo art, the economic value, the value of art and creativity, and the value of the interpretation of ideas.
\end{abstract}

Keywords : Rantak Kudo, Development, Culture

\begin{abstract}
ABSTRAK
Perkembangan Kesenian Rantak Kudo merupakan sebuah fenomena kesenian pertunjukan yang terjadi di daerah Kerinci, dalam penampilan tarian ini tidak dilakukan secara khusus oleh para penari, tetapi ditarikan masyarakat setempat yang saling berbaur sambil mengiringi musik yang dihasilkan dari orgen tunggal dan alat musik tradisional seperti seruling dan gendang, keunikan lainnya adalah tarian ini dilakukan semalaman, artinya para peserta tari ini sanggup menari lebih dari 6 jam secara terus menerus, sehingga masyarakat beranggapan bahwa menari Rantak Kudo disertai dengan unsur- unsur magis didalam pertunjukannya. Pada masa ini kesenian yang berbentuk tarian massal ini hadir di setiap kegiatan dan acara adat kesenian, walaupun disinyalir bahwa kesenian Rantak Kudo ini dipengaruhi dari tari Rantak Kudo yang berkembang di Pesisir Selatan dan juga tari Rantak Kudo dari daerah Rawang. Secara khusus, penelitian ini bertujuan untuk mengungkapkan bentuk dan nilai-nilai budaya kesenian Rantak Kudo di daerah Kerinci. Adapun metodologi penelitian yang digunakan dalam kajian ini adalah penelitian kualitatif post-positivisme, yaitu sebuah metode yang tidak hanya menganalisis yang tanpak, tetapi juga menggunakan, metode, dan dokumen statistik sebagai sarana untuk menempatkan kelompok subjek kedalam populasi yang lebih besar. Adapun hasil kajian dari penelitian ini dapat dikelompokkan menjadi beberapa poin, diantaranya adalah bentuk budaya kesenian Rantak Kudo, nilai budaya yang terandung dalam kesenian Rantak Kudo, nilai ekonomi, nilai seni dan kreativitas, dan nilai interpretasi ide.
\end{abstract}

Kata Kunci : Rantak Kudo, Perkembangan, Budaya 


\section{Pendahuluan}

Kesenian Rantak Kudo, adalah salah satu kesenian yang berkembang di wilayah kerinci, meliputi kabupaten kerinci dan kota sungai penuh yang terletak di provinsi jambi. Rantak Kudo merupakan sebuah kesenian di bidang pertunjukan, ditampilkan pada malam hari yang berisi dengan tarian dan diiringi musik, dalam penampilannya, tarian ini tidak dilakukan secara khusus oleh para penari, tetapi ditarikan masyarakat setempat yang saling berbaur sambil diiringi musik yang dihasilkan dari orgen tunggal dan alat musik lainnya seperti seruling dan gendang, keunikan lainnya adalah tarian ini dilakukan semalaman, para peserta tari ini, sanggup menari lebih dari 6 jam secara terus menerus, sehingga masyarakat beranggapan bahwa menari Rantak Kudo disertai dengan unsur-unsur magis didalam pertunjukannya.

Kesenian yang tumbuh dikalangan masyarakat ini merupakan sebuah fenomena baru dan berkembang sangat pesat di daerah Kerinci, pada masa- masa kebelakang yaitu sebelum tahun 2000, kesenian ini belum pernah terdengar dilaksanakan, apalagi dilaksanakan secara masif pada setiap kegiatan adat dan tradisi budaya Kerinci, tapi pada masa ini kesenian yang berbentuk tarian massal ini hadir di setiap kegiatan dan acara adat kesenian, walaupun disinyalir bahwa kesenian Rantak Kudo ini dipengaruhi dari tari Rantak Kudo yang berkembang di Pesisir Selatan dan juga tari Rantak Kudo dari daerah Rawang, akan tetapi ada perbedaan secara kemasan, bentuk dan penyajian antara tari Rantak Kudo tersebut dengan kesenian Rantak Kudo yang diteliti. kesenian Rantak Kudo selalu ditampilkan di depan umum dan secara bersama- sama baik itu dalam upacara adat maupun kegiatan aktifitas adat lainnya. Kehadiran pertunjukan Rantak Kudo pada awalnya merupakan sebuah hiburan bagi masyarakat, difungsikan sebagai wujud sukacita masyarakat kerinci, atas panen yang berlimpah dan kehidupan yang baik bagi masyarakatnya. Pertunjukan ini kemudian mulai difungsikan dalam acara- acara adat seperti pengangkatan perangkat adat, para depati dan kenduri sako yang diadakan di desa- desa yang ada di Kerinci, Nilai- nilai kearifan tersebut merupakan suatu nilai yang hadir ditengah- tengah masyarakat secara permanen dan dilakukan semenjak lama, hadir berkat pembaharuan yang dilaksanakan oleh seluruh elemen masyarakat pendukungnya.

Perkembangan kesenian Rantak Kudo merupakan sebuah fenomena yang terjadi di wilayah kerinci, kesenian Rantak Kudo yang hadir seringkali diinformasikan sebagai sebuah tradisi yang tidak sepenuhnya lahir dari bagian tradisi yang dilegitimasikan oleh adat kerinci, tetapi merupakan sebuah tradisi yang diakui keberadaannya oleh ninik mamak pemegang legitimasi budaya kerinci, dengan turut andilnya para kaum adat ini maka kehadiran dari kesenian Rantak Kudo diakui sebagai sebuah tradisi dari mereka. Pengakuan dari para pemegang legitimasi dan dilaksanakan hampir di seluruh pelosok kerinci membuat kesenian ini dijadikan sebagai sebuah kesenian yang menjadi bahagian dari kebudayaan mereka,

Perkembangan kebudayaan yang terjadi dalam ruang lingkup masyarakat, serta merta menciptakan nilai- nilai yang terkandung dalam kebudayaan tersebut, nilai nilai ini meliputi enam unsur pokok nilai dalam kebudayaan yaitu : nilai teori, nilai ekonomi, nilai agama, nilai seni, nilai kuasa dan nilai solidaritas (Koentjaraningrat,1980:34). Dalam penelitian ini akan membahas Sejauh mana Perkembangan nilai budaya yang ada dalam kesenian Rantak Kudo.

Penelitian ini menggunakan metode penelitian kualitatif post-positivisme, pemilihan penggunaan kualitatif post-positivisme merupakan sebuah penelitian yang penulis anggap lebih tepat untuk menggali sebuah perkembangan, karena dalam penelitian kualitatif postpositivisme bukan saja hanya menganalisis sebuah masalah dari apa yang tampak, tapi dalam postpositivisme menggunakan, metode, dan dokumen statistik sebagai sarana untuk menempatkan kelompok subjek kedalam populasi yang lebih besar, dalam hal ini post-positivisme mengandalkan beragam metode sebagai cara untuk memahami realita sebanyak-banyaknya.

Penelitian ini dilakukan dengan beberapa metode pengumpulan data seperti, interpretasi dan observasi parsitipatif dengan menggunakan wawancara terbuka dan semi terstruktur dengan para tokoh dan budayawan daerah kerinci, Wawancara ini dilaksanakan sekurangkurangnya dari unsur, pemerintahan, seniman, budayawan dan tokoh yang memahami sejarah daerah kerinci. studi pustaka, observasi. Berikut adalah bagan alur penelitian:

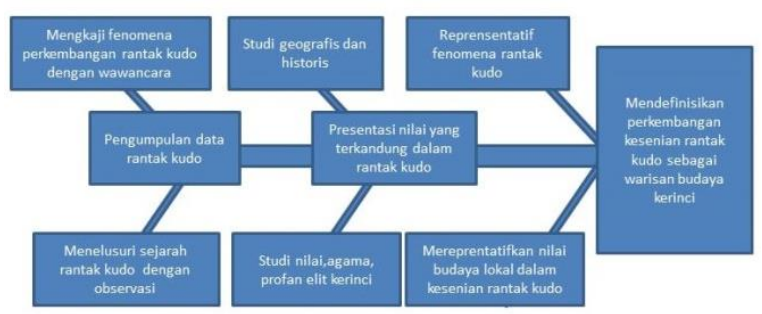

Bagan 1. Bagan alur penelitian

\section{Tinjauan Pustaka}

Studi tentang Kesenian Rantak kudo, masih sedikit penelitian yang dilakukan, baik yang bersifat individu, kelompok masyarakat, maupun pemerintah, dengan adanya rencana penelitian ini merupakan tujuan untuk menambah informasi dan catatan tentang perkembangan kesenian Rantak Kudo, adapun tinjauan penelitian yang berkaitan atau berdekatan dengan penelitian ini didapatkan dari buku- buku, film dokumeter, hasil penelitian yang berkaitan antara lain :

Penciptaan film dokumenter Mahantak Kudo Rasionalisasi Perubahan Terhadap Aktifitas Adat karya Ediantes (2019) yang termuat dalam Jurnal Ranah Seni FBS Universitas Negeri Padang. Dalam tulisan tersebut menceritakan tentang fenomena yang terjadi dalam tradisi budaya masyarakat Kerinci, yaitu pertunjukan 
Rantak Kudo, pertunjukan tersebut semakin lama semakin berkembang di tengah masyarakat, sehingga menjadi topic utama yang dikupas dalam karya ini.

Dalam buku "Budaya Alam Kerinci" ditulis oleh Iskandar Zakaria (2014). Buku tersebut membahas tentang budaya dan tradisi yang ada di Kerinci, termasuk kesenian- kesenian yang berkembang di kerinci. Seperti bentuk kesenian tari Rantak Kudo. Buku tersebut juga mengupas tentang nilai sejarah dan fungsi kesenian Rantak Kudo.

Andreka Boby ( 2013) Dalam penelitian yang berjudul "Studi Terhadap Dua Versi Rantak Kudo untuk pernikahan Di desa Rawang". Dalam penelitian tersebut diuraikan bahwa kesenian Rantak Kudo sebagai bagian dari kebudayaan tradisional hanyalah hiburan semata yang bisa berubah sewaktu-waktu, sesuai dengan standar hiburan pada masanya. Dalam kesenian rantak kudo yang dihadirkan dalam pesta pernikahan juga seringkali memakai peralatan musik modern, seperti orgen, dan sudah jarang yang memakai seruling maupun gendang.

\section{Pembahasan}

\section{Perkembangan Nilai Budaya Dalam kesenian Rantak Kudo}

a. Bentuk Budaya Kesenian Rantak Kudo

Seperti yang telah disampaikan diawal, kesenian Rantak Kudo ini merupakan sebuah kesenian yang tengah berkembang di daerah kerinci, kesenian Rantak Kudo tidak hanya merupakan sebuah tradisi yang telah turun temurun, tetapi juga merupakan sebuah sarana hiburan bagi masyarakat kerinci, yang kehadirannya selalu dinanti-nantikan oleh para penikmatnya, kesenian ini merupakan gabungan antara tarian yang diiringi oleh musik, dan ditarikan secara bersama-sama antara masyarakat dan grup yang membawakan atraksi ini, kesenian ini setelah diamati termasuk kedalam atraksi seni budaya dimana dalam tarian yang dilakukan tidaklah seperti biasanya yang memakai pakem, gerakan dan bentuk yang terpola dari penarinya, sehingga ketika masyarakat menari dalam acara Rantak Kudo mereka lebih banyak melakukan eksplorasi sendiri, gerakan yang dilakukan dengan menyesuaikan dengan musik yang didengar.

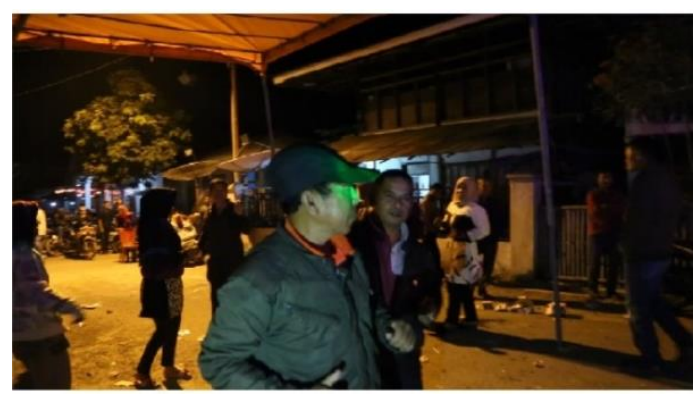

Gambar 1. Suasana masyarakat setempat ikut menari dalam Rantak Kudo

(Dokumentasi: Ediantes, 2020)
Rantak Kudo biasanya dimainkan setelah sholat Isya, sekitar jam 9 malam. Proses awal tarian ini biasanya dimulai dari musik yang dihasilkan oleh gendang yang digunakan, dan syair khas kerinci yang dilantunkan oleh pengasuh Rantak Kudo, peranan gendang dan pengasuh merupakan sangat penting dalam mengatur ritme tarian ini dimana para pengasuh yang melantunkan syair harus tahu persis dimana akan memberikan aba- aba menghentak untuk menaikan mood dari penarinya dan masyarakat yang ikut menari. Dalam setiap grup Rantak Kudo yang ditemui di kerinci memiliki minimal memiliki seorang pengasuh dan penabuh gendang, sehingga penulis menyimpulkan bahwa pengasuh dan penabuh gendang merupakan unsur yang wajib ada dalam Rantak Kudo yang ada di kerinci.

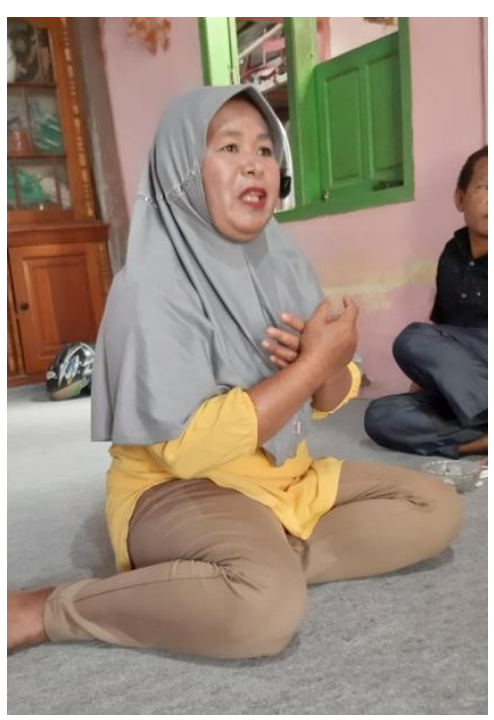

Gambar 2. Salah satu pengasuh tari Rantak Kudo. (Dikumentasi: Ediantes, 2020)

Peranan pengasuh ini merupakan peranan yang sangat penting selain pemain musik, lantunan syair yang dinyanyikan oleh pengasuh juga harus sesuai dengan kondisi dan bentuk kegiatannya, misalnya Rantak Kudo tersebut dilaksanakan untuk kegiatan syukuran salah satu masyarakat, maka syair yang dinyanyikan yang dilantunkan berkaitan dengan acara syukuran tersebut.

Peranan pengasuh juga menjadi pawang dalam kegiatan yang dilaksanakan tersebut, ritual ini merupakan keyakinan yang selalu dijalankan sebelum acara dimulai, pengasuh ini melaksanakan ritual meminta izin kepada mahkluk halus yang diyakini mendiami lokasi tempat kegiatan tersebut, setelah itu pengasuh berkeliling tempat acara dengan membawa kemenyan yang sudah terbakar sehingga dalam beberapa acara Rantak Kudo penulis amati, bau kemenyan sangat menyegat selama kegiatan Rantak Kudo berlangsung. Pada saat ini kesenian Rantak Kudo berkembang dengan baik, setiap kegiatan syukuran atau pernikahan selalu menampilkan kesenian Rantak Kudo sebagai media hiburan mereka.saat ini grup- grup kesenian Rantak Kudo selalu mendapatkan panggilan, shingga kesenian 
Rantak Kudo dijadikan sebagai salah satu sumber ekonomi mereka. Secara struktur pengelolaan kesenian Rantak Kudo yang ada masih belum menerapkan manajemen yang baik, kebanyakan grup- grup Rantak Kudo masih menggunakan sistim pengelolaan secara umum tanpa mengenal sebuah manajemen pengelolaan sebuah grup kesenian.

\section{b. Sampling data grup Rantak Kudo}

Dalam melakukan penelitian kesenian Rantak Kudo yang dilakukan adalah dengan menggunakan metode purposive sampling, teknik ini dilakukan dengan mengambil sampel salah satu grup kesenian Rantak Kudo yang ada di daerah Kerinci, dalam penelusuran yang dilakukan, saat ini terdapat sekitar 17 grup Rantak Kudo yang aktif di kerinci. Salah satunya adalah grup Rantak Kudo Seruling Sakti, Grup Rantak Kudo Seruling sakti berdiri sekitar tahun 2010, pendiri grup ini yaitu ibu Nurmaiti, juga berperan sebagai pengasuh dalam Kesenian Rantak Kudo, awalnya grup ini berdiri merupakan sebuah komunitas yang bergerak dalam bidang musik orgen tunggal. Dikarenakan pendiri grup ini merupakan seorang budayawan kerinci, maka music orgen tunggal dikembangkan juga kesenian Rantak Kudo. alasan pengambilan grup ini menjadi salah satu sampling data adalah karena banyaknya kelebihan dalam penampilannya memainkan kesenian Rantak Kudo ini.,

Pada awal berdirinya grup seruling sakti, mereka memiliki orgen tunggal yang disewakan untuk acaraacara pernikahan, ketika mereka tidak mendapatkan pesanan untuk tampil, maka pemilik dari grup ini berlatih dirumah yang saat ini menjadi tempat latihan Rantak Kudo, pada saat berlatih tersebut selalu dihampiri para pemuda setempat untuk mengasah minat dan bakat yang ada pada mereka, dalam perjalanan waktu, ibu nurmaiti tertarik melihat perkembangan dari kesenian Rantak Kudo, dalam wawancara yang dilakukan oleh ibu nurmati, pada awal kesenian Rantak Kudo hadir, bukanlah seperti saat ini, tari Rantak Kudo awalnya hanya memakai gendang biasa yang jumlahnya hanya tiga buah dan dilantunkan tanpa memakai alat pengeras suara.

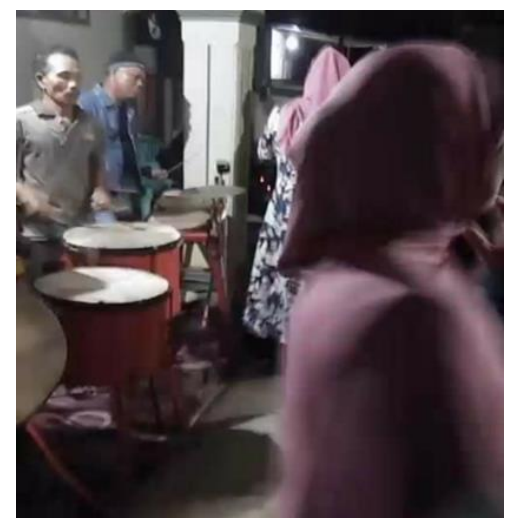

Gambar 3. Salah satu atraksi Rantak Kudo yang masih mempertahankan teknik dan alatnya.

(Dokumentasi: Ediantes, 2020)
Setelah mengamati secara lansung ke lapangan maka, ibu Murmiati memiliki ide bagaimana kesenian Rantak Kudo ini digabungkan dengan memakai orgen tunggal sebagai pengiring dari kesenian ini, ibu nurmiati kemudian mencoba kolaborasi tersebut dengan harapan pembaruan yang dibuatnya dapat diterima sebagai hiburan untuk masyarakat. Dalam penggarapan yang dilakukan juga memakai seruling dalam penampilannya. Seruling ini dipakai untuk membuka acara dan juga digunakan sebagai penjaga mood dalam acara Rantak Kudo.

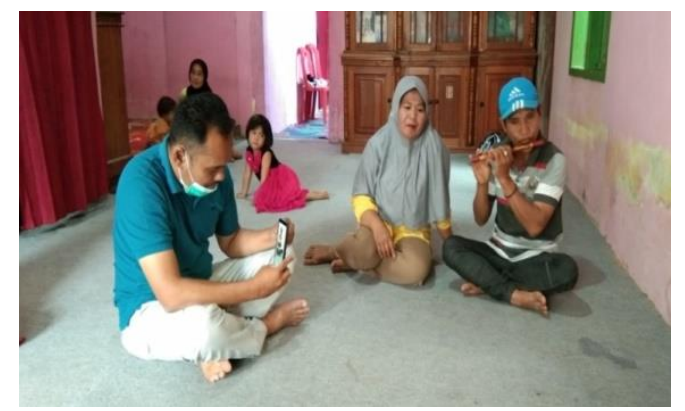

Gambar 4. Pengasuh dan Peniup seruling Rantak Kudo (Dokumnetasi: Ediantes, 2020)

Dalam perjalanan waktu grup Rantak Kudo semakin kreatif dalam melakukan inovasi, inovasi yang dilakukan tentunya tidak menghilangkan atau memudarkan nilainilai ketradisian dalam kesenian Rantak Kudo, inovasi yang dilakukan seperti melibatkan puluhan penari untuk melakukan tarian pembukaan adalah upaya untuk menciptakan kesemarak dalam kesenian ini, sehingga dengan melihat para remaja gadis yang sedang menari maka diharapkan para penonton yang melihat acara ini juga ingin ikut menari.

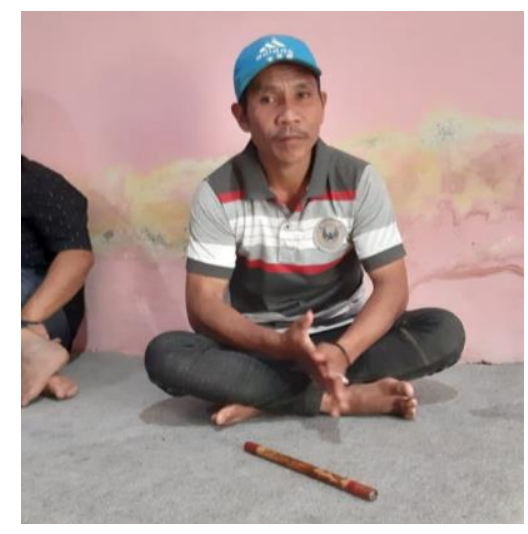

Gambar 5. Peniup seruling Rantak Kudo "Seruling Sakti"

(Dokumnetasi: Ediantes, 2020)

Sebelumnya para penari pembukaan Rantak Kudo seruling sakti hanya berjumlah 5 orang, saat ini ibu nurmiati menggunakan paling sedikit 20 penari dalam sekali tampil, alasan kenapa menggunakan penari yang banyak, ini sebagai upaya ibu nurmiati mengakomodir minat dan bakat, para pemudi di sekitar tempat grup itu 
untuk berlatih dan mengeksplorasi tari- tarian dari kerinci. Melihat animo pemudi setempat untuk mengenali kebudayaannya dimanfaatkan oleh ibu nurmiati untuk membawa serta mereka dalam acara Rantak Kudo ini.

c. Nilai Budaya yang terkandung dalam Rantak Kudo

Perkembangan kebudayaan yang terjadi dalam ruang lingkup masyarakat, serta merta menciptakan nilai- nilai yang terkandung dalam kebudayaan tersebut, nilai nilai ini meliputi enam unsur pokok nilai dalam kebudayaan yaitu : nilai teori, nilai ekonomi, nilai agama, nilai seni, nilai kuasa dan nilai solidaritas . Dalam penelitian ini akan membahas Sejauh mana Perkembangan nilai budaya yang ada dalam kesenian Rantak Kudo.

Dari penelusuran yang dilakukan dan hasil keterangan yang didapat dari ibu nurmatia, beliau menjelaskan bahwa Rantak Kudo yang berkembang dikerinci merupakan hasil dari ide kreatif para penggiat dan pelaku seni di kerinci, memeng ada persamaan nama dengan kesenian Rantak Kudo yang ada di daerah lain, tetapi ada perbedaan yang mendasara dalam penampilan atraksi tersebut. Perbedaan antara lain sebagai berikut :

1. Tema

Dalam penampilan yang dilakukan tema atau motivasi awal terhadap kesenian Rantak Kudo yang ada di kerinci merupakan tema tentang rasa bersyukur dari masyarakat terhadap sebuah kenikmatan yang diberikan pada mereka, contohnya adalah panen hasil berlimpah, syukuran dalam acara pernikahan, syukuran terhadap keberhasilan dalam kampung.

\section{Bahasa}

Bahasa yang dilantunkan dalam syair-syair yang dilantunkan adalah bahasa kerinci, bukan memakai bahasa lain seperti minang dan melayu, syair yang dilantunkan juga merupakan syair-syair tentang rasa syukur terhadap nenek moyang dan tuhan yang maha kuasa untuk kehidupan mereka.

\section{d. Nilai Ekonomi}

Secara ekonomi, kesenian Rantak Kudo belum termanajemen secara professional, seperti yang disampaikan oleh ibu murmatia kebanyakan mereka menerima job tidak mempunyai patokan yang kaku, mereka hanya mempunyai harga minimal dalam sekali manggung, harganya minimal adalah 2 juta rupiah, tetapi terkadang mereka juga meminta lebih dari itu. Kebanyakan praktek yang dilakukan adalah seberapa sanggup dari konsumen untuk mereka. Jika harga yang ditawar oleh konsumen sebanyak harga minimal 2 juta rupiah maka konsumen harus menyediakan transportasi bagi mereka, menginggat kru yang mereka bawa sebanyak 30 orang.

Pembagian jasa yang dilakukan dalam kelompok ini juga unik, karena setelah manggung mereka tidak selalu bagi hasil jasa, tetapi dikumpulkan terlebih dahulu, setelah dirasa cukup maka akan dibagikan kepada para penari. Untuk upah yang diterima oleh para penari sebenarnya jika dikalkulasikan dengan kebutuhan sehari- hari tidaklah mencukupi, rata- rata yang didaptkan oleh penari dalam sekali tampil hanya sekitar 30 ribu rupiah.

\section{e. Nilai Seni dan Kreatifitas}

Nilai seni yang terkandung dalam kesenian Rantak Kudo merupakan nilai- nilai yang lahir dari interpretasi dan kreatifitas seniman dalam memandang kebuadayaan mereka, nilai - nilai interpretasi ini hadir dari pengamatan terhadap kosep psikologis yang ada dan hidup ditengah- tengah masyarakat, mereka memandang bahwa masyarakat membutuhkan sebuah ungkapan terhadap campur tangan tuhan terhadap kenikmatan yang mereka dapatkan.

Penampilan Rantak Kudo dilaksanakan dengan menggunakan media musik membuat suasana meriah dalam pertunjukannya. Gerakan tarian yang dilakukan yang bersifat enerjik, dengan gerak tari menghentakhentak kaki kebawah seperti langkah kuda. Tarian ini diawali dengan masuknya para penari ketengah lapangan, dimulai dengan gerak tarian persembahan, formasi penari berjajar dari depan ke belakang, setelah masuk, maka penari akan membuat formasi lingkaran dan gerakannya sesuai dengan irama tarian.

Setelah sepuluh menit berjalan maka, pengasuh mempersilahkan masyarakat dan penonton untuk masuk ketengah lapangan untuk menari, disini peran pengasuh sangat terasa dalam melantunkan syair- syair supaya meningkatkan mood dan gairah menari masyaraakat tersebut, setelah dirasa masyarakat ramai ikut menari maka para penari grup akan keluar dari lingkaran dan menepi dan mulailah alunan dan ritme musik yang menghentak membawa suasana dan mood masyarakat yang semakin naik.

Dalam suasana puncak ini, terdapat pawang yang berjalan mengelilingi lapangan sambil membawa asap kemenyan, alasan yang didapatkan dilapangan adalah supaya arwah nenek moyang mereka dapat melindungi kegiatan tersebut.

Music yang dimainkan semakin lama semakin tinggi ini membuat masyarakat yang ikut menari semakin bersemangat, hingga akhirnya ada masyarakat yang kesurupan dan akan diamankan ke pinggir lapangan, dalam pemantauan yang dilakukan, stelah ada yang kesurupan maka music yang dimainkan akan diturunkan tempo dan dinamiknya sehingga semangat menari juga menjadi turun, dan ini dilakukan secara berulang, ketika ada yang kesurupan maka dinamik musik akan turun, setelah aman, maka secara perlahan- lahan tempo dan dinamik musik akan kembali naik.

Dalam pengamatan yang dilakukan, musik mempunyai peranan penting dalam suasana yang terjadi, adanya pola berulang-ulang dan cepat membuat suasana semakin meriah, dentuman yang dihasilkan dari pemakaian enam gendang besar yang ditabuh dan alunan string yang dihasilkan dari orgen membuat ritme yang dapat mempengaruhi fungsi otak. Sehingga dengan music seperti itu dapat membuat seseorang dapat kesurupan dalam kegiatan ini. Adapun hal lain karena dengan menari dengan sekian lama dan peranan music juga dipengaruhi oleh aroma kemenyan yang menyengat 
sehingga membuat orang menari dibawah alam sadar mereka, sehingga setelah lelah maka mereka pun kesurupan.

\section{f. Interpretasi Ide}

Masyarakat daerah kerinci pada umumnya memeluk agama islam, mereka adalah pemeluk yang taat terhadap ajaran agama mereka. Dalam konteks psikologis mereka juga mempercayai sesuatu hal yang ghaib, sehingga ada korelasi antara agama islam dengan hal ghaib yang hadir dalam pertunjukan kesenian Rantak Kudo ini, hal ghaib ini dipahami bagaimana rasa syukur mereka juga mereka haturkan untuk mendoakan roh arwah nenek moyang untuk mendapatkan tempat yang layak di sisi sang khaliknya. Hal ini bagi seniman kerinci di interpretasikan, kedalam bentuk syair dan tarian yang menurut pengamatan penulis juga menggunakan unsurunsur metafisika yang mereka lakukan, seperti menggunakan mantra- mantra dan asap kemenyan sepanjang pelaksanaan kegiatan Rantak Kudo.

Dalam pelaksaan kegiatan Rantak Kudo seperti yang disampaikan diatas, yang merupakan sebagai sebuah kesenian hiburan sukaria, maka interpretas yang dihadirkan adalah dengan menggunakan musik dan taran- tarian. Musik yang dihadirkan pada awalnya hanya menggunakan gendang, pada hari ini menggunakan alat musik elektronik. Seperti orgen dan mik, serta seperangkat speaker yang mempunyai kekuatan 10.000 Watt. Penggunaan alat elektronik ini juga dipahami sebagai penguat identitas terhadap konsep sukaria yang ditampilkan dengan sebuah hiburan yang meriah. Perpaduan antara tradisi dan modern ini digunakan pada musik dengan frekwensi dan tempo yang cepat, jika diamati nada yang dipaki adalah nada tinggi dengan pola berulang- ulang sehingga dapat mempengaruhi.

\section{Kesimpulan}

Dari hasil penelusuran ke lapangan maka dapat ditarik kesimpulan bahwa kesenian Rantak Kudo yang ada di daerah Kerinci merupakan sebuah kesenian yang memiliki ciri khas yang berbeda dari daerah lain. Bentuk dan penyajian kesenian ini memiliki nilai- nilai kearifan lokal budaya Kerinci, bagi seniman Kerinci nilai- nilai ini mereka jadikan sebagai isian dalam kesennian ini, penggunaan unsur- unsur magis tak pelak lagi melekat dalam setiap isian yang ada dalam kesenian Kerinci, unsur- unsur ini merupakan sesuatu daya tarik yang kemudian disuguhkan dalam bentuk atraksi budaya bagi penikmatnya. Unsur- unsur ini merupakan sebagai cirikhas yang ada dalam kesenian tradisi kerinci.

kesenian Rantak Kudo bisa dibilang sebgai kesenian rakyat yang berkembang di Kerinci, kesenian ini sangat diminati saat ini, baik untuk kegiatan adat ataupun kegiatan yang diadakan oleh masyarakat. Perkembangan ini juga disinyaalir berkat adanya upaya dari seniman Rantak Kudo untuk mengkreasikan kemasan kesenian ini, kesenian Rantak Kudo pada saat ini mulai dikembangkan, dengan menggunakan music elektrik sehingga paduan unsur music dapat dinikmati oleh masyarakat.

Harapannya kedepan diharapkan kesenian ini merupakan bisa menjadi penghidupan bagi senimanseniman yang bernaung dan ikut serta melestarikan nilainilai budaya ini, sehingga perkembangan ini bukan hanya menjadi sebuah tren tetapi dapat terpelihara menjadi sebuah kebudayaan yang memiliki nilai kearifan local kerinci.

\section{Daftar Pustaka}

Featherstone, Mike.2001. Posmodernisme Dan Budaya Konsumen. Yogyakarta: Pustaka Pelajar.

Graves, Elizabeth E.2007. Asal Usul Elit Minangkabau. Jakarta : Yayasan Obor.

Hadi, Sumandiyo.2006. Seni Dalam Ritual Agama. Yogyakarta : Pustaka.

Hariwijaya M, et al.2004. Tehnik Menulis Skripsi \& Thesis. Yogyakarta: Zenith Publisher.

Kaplan, David et al.1999. Teori Budaya. Yogyakarta: Pustaka Pelajar .

Koentjaraningrat.1974. Kebudayaan Mentalitet dan Pembangunan. Jakarta: Gramedia.

Sachari, Agus. 2002. Estetika. Bandung: ITB.

Sutrisno, Mudji et al. 2005. Teori-teori Kebudayaan. Yogyakarta: Karnisius.

Suwardi, Purnama. 2006. Seputar Bisnis dan Produksi Siaran Televisi. Padang: TVRI SUMBAR.

Suprayogo, Imam et al. 2001. Metodologi Penelitian Sosial Agama. Bandung: Remaja Rosdakarya.

Weber, Max. 2006. Sosiologi. Jakarta : Pustaka Pelajar.

Zakaria, Iskandar.2014.Budaya Alam Kerinci.Jambi 